\title{
Interpreting China: A Study of Five Issues of Arquitectura Viva about contemporary Chinese Architecture
}

\section{Wanli Mo and Li Xiangning}

Tongji University, College of Architecture and Urban Planning, Department of Architecture, Shanghai, China

\section{Abstract}

Since 2004, Arquitectura Viva, a renowned Spanish architectural journal, has published five issues on contemporary architectural practices in China. Three of them offer distinct perspectives through essays and projects, these include: China Boom (AV Monografias 109-110) from 2004, Made in China (AV Monografias 150) from 2011, and Timeless China (Arquitectura Viva 180) published in 2015. Two more issues were devoted to the architecture of global events: Olympic Beijing (Arquitectura Viva 118-119) from 2008 and Shanghai 2010 (Arquitectura Viva 129) put out for the 2010 EXPO. Published over

Corresponding Author: Li Xiangning

lixiangning@tongji.edu.cn

Received: 15 March 2019

Accepted: 25 May 2019

Published: 20 November 2019

Publishing services provided by Knowledge E

(c) Wanli Mo and $\mathrm{Li}$

Xiangning. This article is

distributed under the terms of

the Creative Commons

Attribution License, which

permits unrestricted use and redistribution provided that the original author and source are credited.

Selection and Peer-review under the responsibility of the Architecture across Boundaries Conference Committee. a span of a decade, these five issues interpret a contemporary image of China from different perspectives with respect to architectural practices while building a narrative based on the journal's underlying value orientation. Based on a close reading of these five issues in respect to editorial statements, issue structure and project choice, as well as an interview with their editor-in-chief, this essay attempts to shed light on the journal's latent value orientation, while simultaneously offering a reflection on these values.

Keywords: Contemporary Chinese Architecture, Trans-culture Communication, Architecture Criticism, Arquitectura Viva

\section{Introduction}

Since the 1990s, China has gradually entered the global architectural stage in two ways. On the one hand, China's rapid urbanization process after the Reform and Opening Period has provided tremendous opportunities for foreign architects to work on projects whose scale and complexity could hardly be attained in their respective home countries. As such, China has attracted a number of star architects and large design firms to try themselves in this new, flourishing market. On the other hand, a group of so-called "experimental architects" emerged among Chinese architects, their designs were led by discontent toward complete assimilation of Western modernist ideas. ${ }^{\circledR}$ Their search for cultural continuity as well as a balance between modernity and 
tradition soon gained international recognition, which in turn supported their gradual elevation from the periphery to the center of the architectural stage at home.

The dynamic and complexity of this two-pronged process was no doubt captured by media. A number of international journals such as 2G, Architecture + Urbanism, AREA, etc. have covered the bustling architectural scene in China from different perspectives. Among them, Arquitectura Viva stands out due to its sustained interest in China. Between 2004 and 2015, the magazine published five thematic issues on contemporary Chinese architecture. Read first-hand, they provide a perspective to follow the path of architectural development in China. More importantly, they offer an opportunity to examine how China, specifically contemporary Chinese architecture, is interpreted by an international audience. What is the drive behind covering architecture in China? What are the recognized, selective qualities of chosen projects? To cast a light on these questions, the essay proposes a close reading of these five issues of Arquitectura Viva to expose its latent value orientation and, furthermore, develops a preliminary critique of the style of reporting represented by Arquitectura Viva regarding its positive and negative impact on contemporary Chinese architecture.

\section{Purpose}

The objective of this study is three-fold. First, while there are a number of existing studies on domestic architectural journals and how they review the architectural development in contemporary China, the same is lacking for international architectural journals. ${ }^{2}$ Thus, the study aims to fill such research gaps and provide insights from a transcultural perspective. Second, the intention is to transcend the superficial content of the reporting and capture the essence of their structure in an effort to shed light on the journal's latent value orientation. Finally, based on the results of the study, a preliminary critique of such reporting is developed to reflect on the impact of international media on contemporary Chinese architecture.

\section{Scope, Approach and Method}

This study focuses on Arquitectura Viva's five thematic issues about China. As a renowned Spanish architectural journal under the editorial direction of Luis-Fernandez Galiano since 1988, the magazine has covered a wide range of topics and phenomena in Spain and around the world. ${ }^{3}$ Among its five China issues, China Boom (AV Monografias 109-110, 2004), Made in China (AV Monografias 150, 2011), and Timeless China 
(Arquitectura Viva 180, 2015) offer different perspectives through essays and selected projects. The remaining issues, Olympic Beijing (Arquitectura Viva 118-119, 2008) and Shanghai 2010 (Arquitectura Viva 129, 2010) put out for the EXPO 2010 are devoted to the architecture of global events. The study proposes a comparative approach to analyze these five issues in respect to editorial statement, issue structure, and reported projects, and is further supported by an interview with Luis-Fernandez Galiano. As the representation of each project through texts and photographs builds up the narrative of each issue, the study engages a textual analysis of how projects are reported as well as an analysis of visual materials. In terms of texts, a quantitative content analysis borrowed from communication studies is engaged to identify keywords and the style of reporting [1]. As to visual materials, the analysis considers the image as an object and focuses on an understanding of what the image is, how it is framed, and why it exists within a particular context [2]

\section{From China Boom to Timeless China}

Merely reading the titles of the five issues of Arquitectura Viva, one can already discover a shift in attention. While China Boom, Olympic Beijing and Shanghai 2010 suggest a concern about the present and global events, Made in China and Timeless China imply a connection to the past and locality. This impression is further strengthened by the choice of the respective cover imagery. The first batch shows works by foreign architects in China: PTW's National Swimming Center, Herzog \& de Meuron's National Stadium for the Olympic Games and EMBT's pavilion of Spain at the Shanghai EXPO 2010. However, the second batch shows projects designed by Chinese architects: Philip F. Yuan's Silk Wall, and Wang Shu and Lu Wenyu's Wen Village. While the former projects are presented as a contemporary spectacle with their formal and structural complexity, the latter are cropped views focusing on their materiality, implicitly expressing an emphasis on local characteristics and culture. (Figure 1) The first impression of these five issues already establishes a division between them, yet further findings require a close reading of their content.

\subsection{Editorial statement}

For each issue of Arquitectura Viva, the editor-in-chief Luis-Fernandez Galiano contributes an editorial statement which explains its theme and intention. For the issues concerning China, rather than being introductory pieces on architectural projects, they 


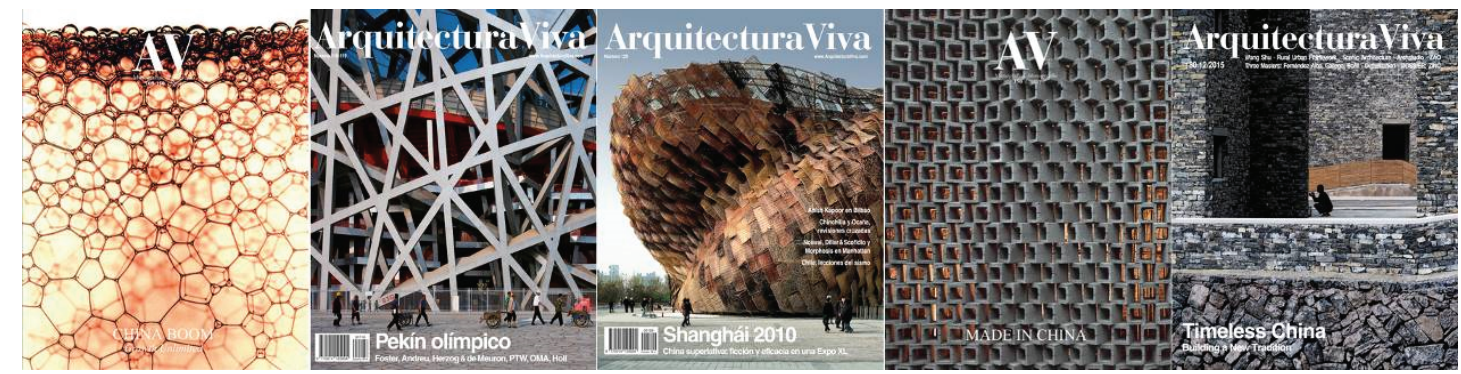

Figure 1: Covers of the five China issue.

tend to focus on the political and economic background. China Boom describes the stunning growth of China with economic statistics and business cases. Both Beijing Olympics and Shanghai 2010 comment on the unprecedented organizational scale of the events, while Made in China places an emphasis on the important role that China has played in international trading. With these facts being stated, they indicate a positive prospect on China's rising role in the world. While China Boom opens with the question "A Pacific century, an Asian century or a Chinese century?" and points out potential social and environmental challenges China faces, the confidence in China becomes far more affirmative in Made in China [3]. There, Galiano writes: "An emerging prosperity that steers the country towards the role of hegemonic power, with an increasing and already overbearing presence in Asia, Africa and Latin America" [4]. This is after the Beijing Olympic Games "symbolically endorsed China's protagonism in today's world" and the Shanghai EXPO "amazed the planet with the largest fair ever" while most of the world was still suffering from the 2008 financial crisis [5]. These statements reveal Arquitectura Viva's motivation of placing its attention on China. Being an internationally active critic, Luis-Fernandez Galiano first visited China in 1976, two years before the Reform and Opening policy was officially put forward. Since then, he has traveled to China several times for international competition reviews and university lectures. During his first trip to China he was given a tour of rural regions and new urban developments, piquing his interest in China's development. Galiano himself could be described as a witness of contemporary Chinese architecture from the outside and he considers Arquitectura Viva a platform to present and record the transformations in China for the world. ${ }^{\oplus}$

The role that Arquitectura Viva has played as a recording platform is corroborated and explained in Timeless China. The development process is summarized into a threephase movement of "opening, assimilation, return" [6]. China Boom, Olympic Beijing and Shanghai 2010 belong to the first phase with prominent presence of foreign architects in China as a sign, and a result, of the opening-up. Made in China signals a second 
phase during which Chinese architects began to change the architectural landscape by assimilating both Modern and intrinsically Chinese traditions. Timeless China suggests a third phase, in which further efforts are made by Chinese architects to seek, or in Galiano's word "return," to China's cultural roots. For Galiano, the triple phase is a natural reaction mechanism of a country which was once cut off from the world and later returned to global conversation. He compares the situation in China with Spain in the 1980s and 1990s. After Francisco Franco's regime ended, internationally renowned architects were invited to build symbolically significant projects in Spain due to both its intention of showing openness to the world and a lack of confidence in its native architects. It was only decades later that Spanish architects were recognized at home and abroad which helped Spain become one of the most successful countries exporting its architects to the world. ${ }^{(5)}$

\subsection{Issue structure}

Each issue consists of a number of essays and projects related to its particular theme. Although the structure is straight-forward, what matters is the title assigned to each section and the selection of essays and projects. A comparison of these aspects (Figure 2 ) indicates the structural changes of Arquitectura Viva's focus. Based on the summary in Figure 2, the following observations can be made:

First, the selection of essays indicates a gradually deepened understanding of China. The three issues within the first cluster tend to give a critical overview of China's history and contemporary development and their essays are mostly written by foreign scholars. The tension between modernity and tradition in China is a common focus for them and is visually intensified by juxtaposed images of historic monuments and contemporary high-density residential towers, almost resembling a barcode texture. The essay by Juan Carlos Sancho, a Spanish architect who has practiced in Shanghai, summarizes necessity, variability, and speed from his own experience as the symptomatic characteristics resulting from a frenetic market situation. The two issues from the later phases tend to invite Chinese scholars to write on issues more specifically related to architecture in an in-depth way. For instance, Li Xiangning's "Key Concepts of Chinese Architecture Today", which includes "bigness" and "swiftness" as phenomena of architectural practice in China, as well as "uncertainty" and "spatial politics" as part of the essential operational framework, could be viewed as an extended and detailed version of Sancho's three points. 




Figure 2: Issue Structure Comparison.

Second, the weight of reported projects gradually shifts from those by foreign architects to those by Chinese architects and from iconic projects that are geographically located in China, to ones that are culturally rooted in China. In China Boom, twentyfour projects by sixteen foreign architects take up two-thirds of the issue's volume, undoubtedly overwhelming the six projects by six Chinese architects. The defensive situation of Chinese architects is further implied by the section title: Foreign Legion and Home Architects. It's worth noticing that the introduction of each section features two images: one is an artwork by a contemporary Chinese artist, while the other shows an exemplary image from one of the reported projects. The Foreign Legion section is introduced by Cai Guo-Qiang's "Inopportune: Stage One" combined with the grid facade of Riken Yamamoto's Jian Wai SOHO. The Home Architects section is represented by Wang Du's "Defile" and a close-up view of a concrete wall in Liu Jiakun's Luyeyuan Sculpture Museum. (Figure 2) In the contrast between Cai's colorful pop-art imagery and Wang's deliberately staged scene, which responds to "western's Goliath arrogance", as well as between the deadpan façade of Yamamoto and the rough surface of low-tech board formwork of Liu Jiakun the following comparisons are intentionally highlighted: universal technology and local craft, extended space and bounded place, visual representation and bodily experience [7]. While no obvious preference for either of these two concepts is expressed in China Boom, the selection 
of projects, as suggested by section 4.3 , indicates an inclination towards the latter in the subsequent issues.
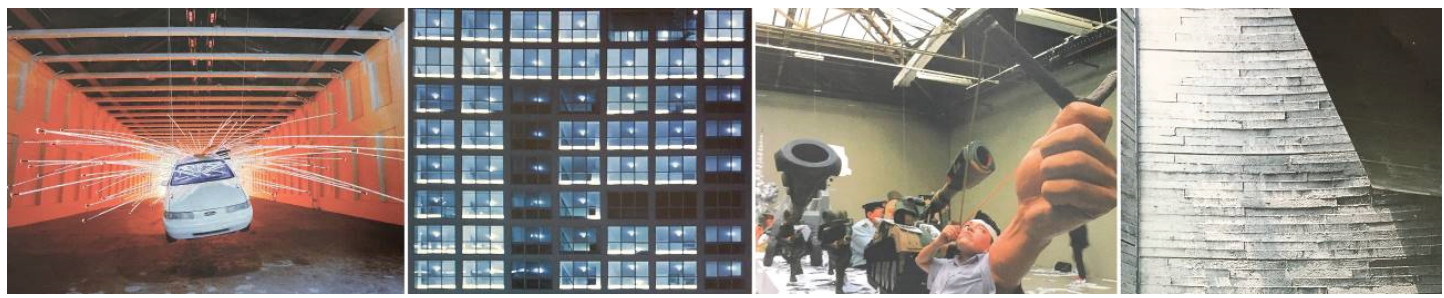

Figure 3: Images from China Boom: (from left to right) Cai Guo-Qiang's "Inopportune: Stage One", Riken Yamamoto's Jian Wai SOHO, Wang Du's "Defile", Liu Jiakun's Luyeyuan Sculpture Museum.

\subsection{Reported projects}

This chapter focuses on an analytical comparison of the projects covered in the China Boom, Made in China, and Timeless China issues of Arquitectura Viva as the projects in Olympic Beijing and Shanghai 2010 were built for specific events. These three issues are first compared concerning the reported project' status, location, scale, and program. (Figure 3) Further analysis is carried out on how each project is textually described. Based on their frequency, a number of keywords are identified and are divided into four categories: massing, context, construction technique, and materiality. (Table 1) Together, they demonstrate a shift in the choice of reported projects from bold forms and gigantic volumes to cluster-like and modest projects, from technologically advanced structures to materials and techniques connected to tradition. They also show a constant emphasis on contextuality and materiality as almost the same set of keywords are used to describe projects of a variety of scale and program. While it is no doubt that in the past years, Chinese cities continue to build large-scale iconic projects and some of them have demonstrated outstanding design quality, Arquitectura Viva chooses to focus on smallscale projects which are mostly located in the periphery areas and seeks a topological relationship with the site, a typological connection with the tradition, and a material re-interpretation of the past. 


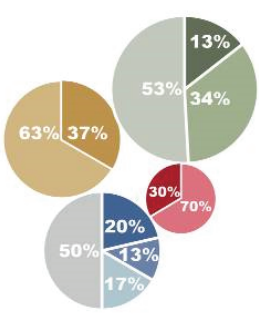

2004 China Boom

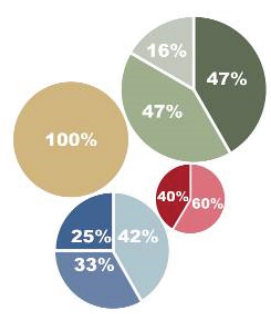

2011 Made in Chin

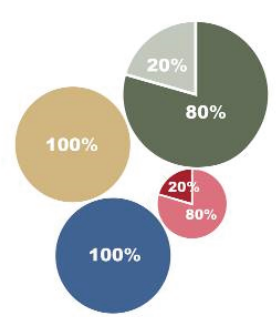

2015 Timeless Chin

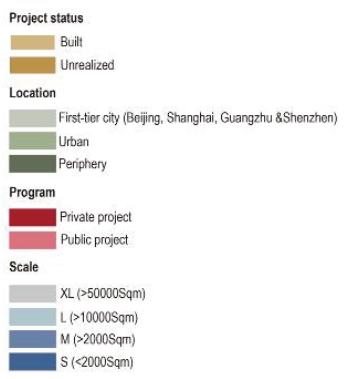

Figure 4: Project summary.

TABLE 1: Key words analysis.

\begin{tabular}{|c|c|c|c|c|}
\hline & & $\begin{array}{l}\text { China Boom (30 } \\
\text { projects) }\end{array}$ & $\begin{array}{l}\text { Made in China (12 } \\
\text { projects) }\end{array}$ & $\begin{array}{l}\text { Timeless China ( } 5 \\
\text { projects) }\end{array}$ \\
\hline \multirow[t]{2}{*}{ Massing } & $\begin{array}{l}\text { Formal } \\
\text { Strategy }\end{array}$ & $\begin{array}{l}\text { In foreign architect's } \\
\text { section, "bold", } \\
\text { "dramatic", } \\
\text { "technological", } \\
\text { "sculptured", } \\
\text { "organic", and "iconic" } \\
\text { are used the most, } \\
\text { with "bold" being } \\
\text { used to describe three } \\
\text { projects. In the home } \\
\text { architects' section, } \\
\text { "cluster" and } \\
\text { "ramp/catwalk" are } \\
\text { most commonly } \\
\text { mentioned. }\end{array}$ & $\begin{array}{l}\text { "Interstitial" space is } \\
\text { identified in five } \\
\text { projects; "cluster" } \\
\text { appears in two } \\
\text { projects. "Roof" and } \\
\text { "ramp" are also } \\
\text { mentioned as formal } \\
\text { features. An exception } \\
\text { is Ma Yansong's Ordos } \\
\text { Museum, which is } \\
\text { described as } \\
\text { "sculptural", "organic" } \\
\text { and "fluid". }\end{array}$ & $\begin{array}{l}\text { "Cluster", } \\
\text { "Labyrinthian", } \\
\text { "pitched roof", "ramp" } \\
\text { and "exterior gallery" } \\
\text { are mentioned equally } \\
\text { as formal features. }\end{array}$ \\
\hline & Scale & $\begin{array}{l}\text { Numbers referring to } \\
\text { the bigness of the } \\
\text { buildings are quoted } \\
\text { eight times in total. }\end{array}$ & $\begin{array}{l}\text { Numbers referring to } \\
\text { the volume of the } \\
\text { building are only } \\
\text { quoted two times in } \\
\text { Ma Yansong's Ordos } \\
\text { Museum }\end{array}$ & $\begin{array}{l}\text { No numbers referring } \\
\text { to area or volume } \\
\text { appear in the text } \\
\text { description. }\end{array}$ \\
\hline \multirow[t]{3}{*}{ Context } & Culture & $\begin{array}{l}\text { "Tradition" is } \\
\text { mentioned in ten out } \\
\text { of thirty projects, with } \\
\text { three of them by } \\
\text { Chinese architects. }\end{array}$ & $\begin{array}{l}\text { "Tradition" is } \\
\text { mentioned in seven } \\
\text { out of twelve projects. }\end{array}$ & $\begin{array}{l}\text { "Tradition" is } \\
\text { mentioned in all five } \\
\text { projects. }\end{array}$ \\
\hline & $\begin{array}{l}\text { Typological } \\
\text { Reference }\end{array}$ & $\begin{array}{l}\text { "Courtyard" appears in } \\
\text { five projects, while } \\
\text { "alleyways" and } \\
\text { "urban fabric" are } \\
\text { each mentioned once. }\end{array}$ & $\begin{array}{l}\text { "Courtyard" appears in } \\
\text { three projects, with } \\
\text { "Lifang", "Tou Lou", } \\
\text { "Chinese Garden", } \\
\text { "Long Tang" } \\
\text { mentioned once. }\end{array}$ & $\begin{array}{l}\text { "Courtyard" appears in } \\
\text { three projects, with } \\
\text { "Chinese Town" and } \\
\text { "Hu Tong" mentioned } \\
\text { once. }\end{array}$ \\
\hline & $\begin{array}{l}\text { Topographical } \\
\text { Relationship }\end{array}$ & $\begin{array}{l}\text { The relationship with } \\
\text { the terrain is } \\
\text { highlighted in five } \\
\text { projects, with "blend" } \\
\text { mentioned in two, } \\
\text { "adapt" in one, and } \\
\text { "organize" in two. }\end{array}$ & $\begin{array}{l}\text { "Blend" is mentioned } \\
\text { in four projects, while } \\
\text { "integration" with the } \\
\text { landscape is } \\
\text { mentioned in three } \\
\text { projects. }\end{array}$ & $\begin{array}{l}\text { "Integration" with the } \\
\text { landscape is } \\
\text { mentioned in three } \\
\text { projects, with one } \\
\text { project described as } \\
\text { "embedded". }\end{array}$ \\
\hline
\end{tabular}




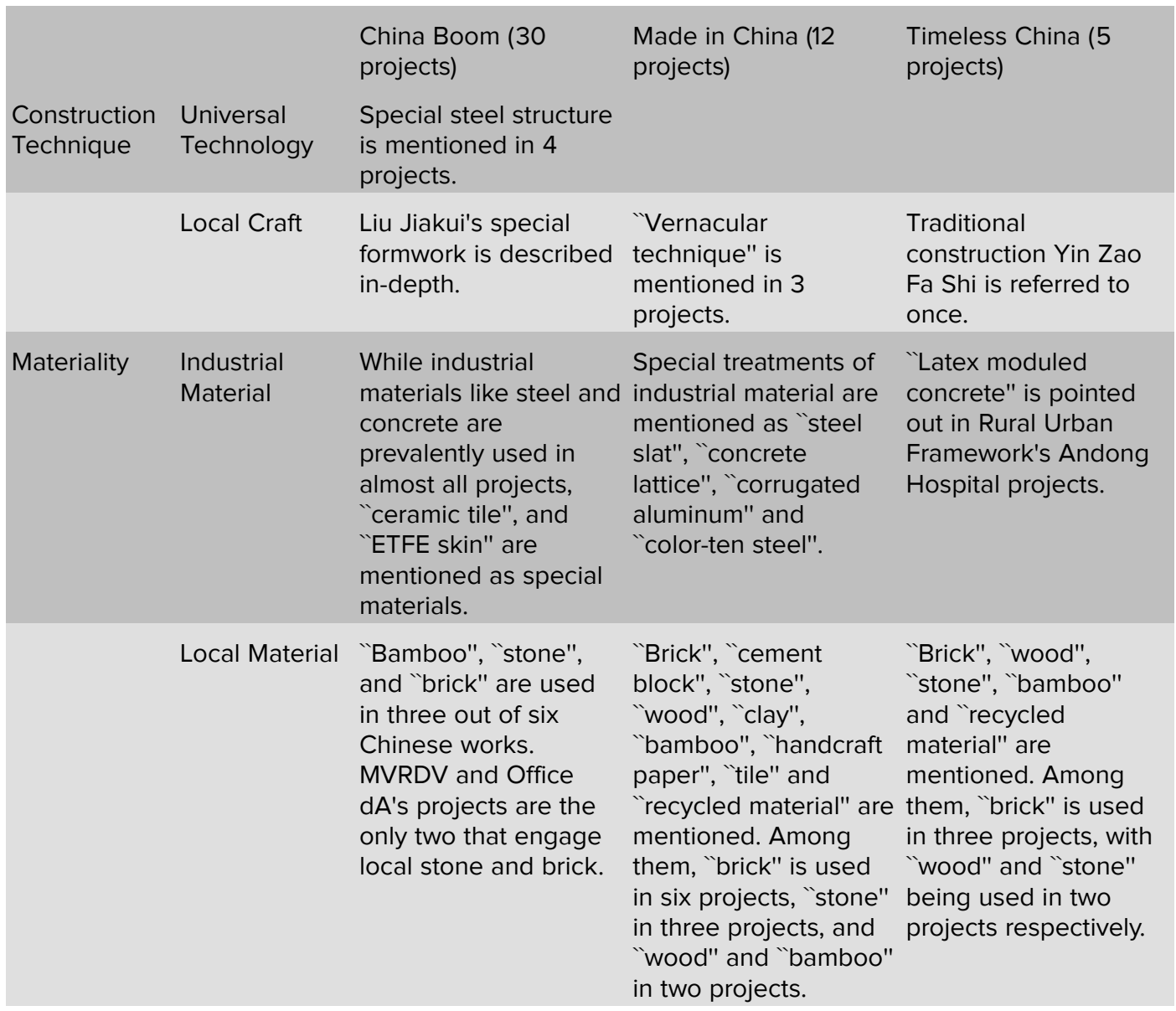

It's important to note that while tradition remained a constant keyword in all three issues, its connotation changed. In China Boom, tradition is usually linked to visual properties, such as colors and patterns. Thus, the strategies employed for its understanding tend to be a visual simulation and symbolic interpretation. For example, both Herzog \& De Meuron's proposed master plan for a university campus in Beijing and Office dA's proposed Tongxian Art Center engage in a literal translation of traditional urban texture as a pattern to be mapped into plan layout and façade panels. In both Made in China and Timeless China, tradition bears a stronger connection to in-depth layers of culture that manifest themselves in architectural types and local crafts. As such, its interpretation is a re-invigoration via adaption. For instance, Tulou, a traditional housing type of the Hakka people, is transformed into a new type of low-income public housing by Urbanus, while old materials are recycled and re-used in projects by Wang Shu and Lu Wenyu, as well as by Rural Urban Framework. The experience of tradition thus becomes tactile rather than visual. 


\subsection{Value orientation and a critique}

From the findings above, it is clear that contextuality and materiality are the two most valued aspects in Arquitectura Viva's reports and suggest a framework for finding a Chinese root. ${ }^{\circ}$ To some extent, the value orientation reflected by these aspects aligns with Kenneth Frampton's concept of critical regionalism. To work with topography is described by Frampton as "engagement in the act of cultivating the site". To blend architecture into context is, in Frampton's words, by "layering into the site, the idiosyncrasies of place find their expression without falling into sentimentality". Materiality is related to tectonics, which, for Frampton, is a "potential means for distilling play between material, craftwork, and gravity" [8].

A brief review of other international journals published around the same time indicates a similar trajectory of shift in interests from the dazzling construction scenes in Chinese cities to a culturally-rooted Chinese architecture. For example, while in 2005, Italian journal AREA's special issue China Overview presents "a critical reading of the Chinese reality on the basis of a study of its two biggest and most important metropolitan cities, Beijing and Shanghai", its 2014 special issue Chinese Identity covers thirteen "works of extraordinary architectural value precisely because of their links to a cultural milieu which abounds in history, in traditions and awareness and which is willing -- and this by now applies to the whole country -- to experiment." [9] Such shift also appears in Japanese magazine Architecture + Urbanism's two special issues: Architecture in China (2006) and Architects in China (2015). However, among these journals, Arquitectura Viva most firmly and clearly expresses a value orientation toward a discourse of critical regionalism.

An emphasis on contextuality and materiality is necessary and crucial, especially as China experiences dramatic changes through globalization. While Arquitectura Viva acts as a recording platform, its communication of certain qualities, values, and projects on a global scale also represents a guiding and feedback mechanism for architectural practice in China, not only for architects, but also for the government and developers. As Galiano mentions, international coverage played an important role in the recognition of the experimental group of architects in China. However, the question that still needs to be addressed is whether they are comprehensive enough to represent the rich and complex reality of China and whether the search of Chinese roots is the only possible direction. While tradition is of paramount significance for Chinese architecture, it also runs the risk of solidifying it into a stereotype or a recipe made up of specific materials and formal strategies. Meanwhile, Made in China indicates a far larger range of 
possibilities as the projects by MAD, Atelier Deshaus, and Neri \& Hu could hardly fit into the above-mentioned formula. Yet these projects also have their roots in the reality of China, a reality that belongs to the present and is shaped by globalization. Furthermore, social considerations are more or less understated in this set of values. While architects design spaces and create shapes, they always have to deal with social reality and may attempt to make a difference in it. Projects such as Wang Shu and Lu Wenyu's Wen Village and Rural Urban Framework's Andong Hospital produced considerable improvement for the villagers' living conditions, but these aspects are, to some extent, overlooked.

\section{Conclusion}

From China Boom to Timeless China, Arquitectura Viva's five China issues have built a narrative from geographically Chinese architecture to culturally Chinese architecture. On one hand, it has recorded the development of contemporary Chinese architecture. On the other hand, it has produced an indirect impact on it by putting an emphasis on contextuality and materiality. While their significances are beyond question, it should be noted that other values are also crucial in architecture.

\section{Funding}

This work was supported by the National Natural Science Foundation of China under Grant No. [51878451].

\section{Acknowledgement}

The authors would like to thank their colleagues for their contributions and support to the research. They are also thankful to all the reviewers, who gave valuable inputs to the manuscript and helped in completing the paper.

\section{Conflict of Interest}

The authors have no conflict of interest to declare. 


\section{Notes}

(1) Experimental architects refers to a group of independent architects in China that emerged in the 1990s. Although the group has never been accurately defined, practices that search for an alternative to total acceptance of modernity is generally considered as the common characteristic of the group. Today, the concept has generally been historicized for various reasons.

(2) A number of researches have bee carried out on domestic architectural journals. See: Ding, G. (2015). Constructing a Place of Critical Architecture in China: Intermediate Criticality in the Journal Time + Architecture. London,UK: Routledge; Architectural Journal.(2014) Z1.

(3) Luis-Fernandez Galiano is also a critic and theorist whose publications reached a wide audience while also serving as a jury member for various international competitions and awards.

(4) Based on author's interview with Juan Fernandez-Galiano.

(5) Ibid.

(6) Ibid.

\section{References}

[1] Krippendorff, K. (2004). Content Analysis: An Introduction to Its Methodology. London:SAGE Publications Ltd.

[2] Banks, M. (2001) Visual Methods in Social Research. London: SAGE Publications Ltd; pp. 2 -- 12.

[3] Galiano, J. (2004). China Boom. AV Monografias, vol. 109-110, pp. 3.

[4] Galiano; J. (2011). Made in China. AV Monografias, vol. 150, pp. 3.

[5] Olympic Beijing. Arquitectura Viva, vol. 118-119, pp. 3; Galiano, J. (2010). Shanghai 2010. Arquitectura Viva, vol. 129, pp. 3.

[6] Galiano; J. (2015). Timeless China. Arquitectura Viva, vol. 180, pp. 3.

[7] Galiano, J. (2004). China Boom. AV Monografias, vol. 109-110, pp.122.

[8] Frampton, K. (2016). Towards a Critical Regionalism: Six Points for an Architecture of Resistance, in The Anti-Aesthetic: Essays on Postmodern Culture. Hal Foster, NY: The New Press. pp. $26-28$.

[9] Casamonti, M. (2004). Chinese Identities. AREA, No.137, pp2-7. 